\title{
Analisis Pengaruh Peningkatan Durasi Waktu Terhadap Kuat Tekan Mutu Beton K-250 Pasca Kebakaran
}

\author{
Analysis of the Effect of Increasing Time Duration on \\ Compressive Strength of K-250 Concrete Quality Post Fire
}

\author{
Sari Utama Dewi ${ }^{*}$, Arian Yoga Nanda ${ }^{2}$ \\ ${ }^{1}$ Universitas Muhammadiyah Metro \\ ${ }^{1}$ Universitas Sang Bumi Ruwa Jurai \\ Email: saridewi.dewi1981@gmail.com
}

\begin{abstract}
Abstrak
Ada banyak faktor yang menyebabkan kerusakan pada suatu bangunan, antara lain ialah usia dan bencana kebakaran. Banyak akibat yang ditimbulkan dari bencana ini, dengan adanya temperatur yang sangat tinggi diduga akan mengakibatkan beton berubah sifat maupun kekuatannya. faktor utama yang membuat beton kan mengalami perubahan ialah temperatur tinggi yang diterima beton, selain temperatur durasi juga sangat berpengaruh terhadap perubahan sifat dan kekuatan beton. Maka dari itu, penelitian ini bertujan membahas tentang kekuatan struktur beton khususnya melihat perbandingan atau penurunan kekuatan beton pasca bakar dengan beton normal. Penelitian ini dilakukan dengan memberikan durasi pembakaran pada benda uji yaitu 3 jam, 6 jam, 9 jam dengan mutu beton yang sama pada umur setelah 28 hari. Dan mengganti penyiraman dengan perendaman selama 4 menit setelah benda uji di bakar. Pembakaran dilakukan dengan menggunakan oven dengan tempratur $200^{\circ} \mathrm{C}$. Dari hasil penelitian kuat tekan yang diperoleh, pada umur benda uji lebih dari 28 hari serta perendaman selama 4 menit, kuat tekan beton mengalami penurunan sebesar $20,13 \mathrm{~kg} / \mathrm{cm} 3$ yaitu (7,96\%) pada durasi pembakaran $3 \mathrm{jam}, 44,61 \mathrm{~kg} / \mathrm{cm} 3(17,6 \%)$ pada durasi $6 \mathrm{jam}$, ddan $50,32 \mathrm{Kg} / \mathrm{cm} 3$ yaitu $(19,9 \%)$ pada durasi 9 jam, Pada tiap variasi durasi pembakaran, beton tidak mengalami perubahan fisis yang signifikan.
\end{abstract}

Kata kunci: Peningkatan Durasi Waktu, Kuat tekan Mutu, Beton K-250, Kebakaran

\begin{abstract}
There are many factors that cause damage to a building, among others are age and fire disaster. Many of the consequences of this disaster, with very high temperatures are expected to cause the concrete to change its properties and strength. The main factor that causes the concrete to change is the high temperature received by the concrete, in addition to the duration temperature, it is also very influential on changes in the properties and strength of the concrete. Therefore, this study aims to discuss the strength of the concrete structure, especially looking at the comparison or decrease in the strength of post-combustion concrete with normal concrete. This research was conducted by giving the duration of burning on the test object that is 3 hours, 6 hours, 9 hours with the same quality of concrete at the age after 28 days. And replace watering with immersion for 4 minutes after the test object is burned. Burning is done using an oven with a temperature of $200^{\circ} \mathrm{C}$. From the results of the compressive strength research obtained, at the age of the test object more than 28 days and soaking for 4 minutes, the compressive strength of the concrete decreased by $20.13 \mathrm{~kg} / \mathrm{cm} 3$ that is $(7.96 \%)$ at the duration of 3 hours of combustion, $44.61 \mathrm{~kg} / \mathrm{cm} 3(17.6 \%)$ at a duration of 6 hours, and $50.32 \mathrm{Kg} / \mathrm{cm} 3$ that is (19.9\%) at a duration of 9 hours. In each variation of the duration of combustion, the concrete did not experience significant physical changes.
\end{abstract}

Keywords: Increased Time Duration, Quality Compressive Strength, K-250 Concrete, Fire 


\section{PENDAHULUAN}

Beton adalah bagian struktur bangunan dan salah satu central penting dalam suatu pembangunan. Beton menjadi titik penting dalam menunjang kekuatan suatu bangunan. Beton sudah banyak dikembangkan dalam pembuatan maupun agregat campurannya. Hampir segala jenis pembangunan infrastruktur tidak terlepas dari kebutuhan akan beton dan beton bertulang. Perkembangan yang sangat dikenal dan sering dipakai ialah kombinasi antara material beton dan tulangan baja yang sering disebut beton sederhana. Beberapa bagian struktur gedung ialah kolom, balok, plat lantai, sloof dan lain sebagainya [1].

Beton mempunyai karakteristik dan permasalahan yang selalu harus di amati dan di telusuri lebih jauh. Permasalahan beton pada umumnya ialah beban yang diterima, gaya, dan temperatur dan masih banyak lagi. Dan kali ini saya akan membahas perubahan temperatur yang di terima beton dan apa sajakah pengaruh terhadap beton tersebut setelah menerima perubahan temperatur tersebut. dikarenakan apa bila terjadinya perubahan suhu yang cukup signifikan seperti perubahan suhu temperatur panas, karakteristik beton sudah pasti berubah. dari mulai kekuatan beton tersebut. Permasalahan temperatur panas tersebut terjadi pada masalah kebakaran. Secara keseluruhan masalah yang akan diamati ialah bagaimana kondisi dan perbandingan kuat tekan beton setelah menerima tempratur tinggi atau pasca terbakar sebelum dan sesudah dengan durasi pembakaran yang berbeda-beda [2].

Dengan adanya penelitian ini kita dapat mengetahui seberapa besar presentase beton pasca bakar bisa digunakan kembali, sesuai lama durasi terbakar dan temperatur yang diterima pada saat kebakaran. Setelah gedung mengalami kebarakan tidak sematamata langsung mengalami pembongkaran dan pergantian struktur, kita bisa menganalisa apakah beton mash layak untuk di rehabilitasi atau dipakai kembali setelah menerima sedikit sentuhan perbaikan sebelum memasuki tahap pembongkaran.

Cornelis, dkk melakukan penelitian mengenai Kajian Kuat Tekan Beton Pasca Bakar dengan dan tanpa Perendaman berdasarkan Variasi Mutu Beton. Pembakaran dilakukan pada suhu $400 \mathrm{oC}$ dan lamanya pembakaran selama 3 jam.Perendaman beton pasca bakar dilakukan selama 14 hari. Hasil dari penelitian ini menunjukkan bahwa berdasarkan variasi mutu beton $(15 \mathrm{MPa}, 20$ $\mathrm{MPa}, 22 \mathrm{MPa}$, dan $25 \mathrm{MPa}$ ) didapatkan nilai kuat tekan rata-rata pada pada perlakuan standar menghasikan kuat tekan rata-rata sebesar 26,00 $\mathrm{MPa}$, 26,67 $\mathrm{MPa}, 28,44 \mathrm{MPa}$ dan 29,48 MPa. Pada perlakuan beton pasca bakar dengan perendaman menghasilkan kuat tekan rata-rata sebesar 19,41 $\mathrm{MPa}$, 22,37 $\mathrm{MPa}, 24,15 \mathrm{MPa}$ dan 25,85 $\mathrm{MPa}$. Sedangkan pada perlakuan beton pasca bakar tanpa perendaman menghasilkan kuat tekan rata-rata sebesar $24,89 \mathrm{MPa}, 25,78$ MPa, 28,67 MPa dan 30,52 MPa. Penurunan kekuatan beton pasca bakar tanpa perendaman pada mutu beton $15 \mathrm{MPa}$ dan 20 MPa sebesar $4,274 \%$ dan 3,333\% dan peningkatan pada mutu beton $22 \mathrm{MPa}$ dan 25 MPa sebesar $0,781 \%$ dan 3,518\%. Penurunan kekuatan beton pasca bakar dengan perendaman sebesar 25,356\%, $16,111 \%, 15,104 \%$ dan 12,312\% [3].

Sedangkan Atmaja, dkk melakukan penelitian mengenai Struktur Beton Pasca Kebakaran terhadap Kuat Tekan Beton dan Karakteristik Beton. Penelitian ini menggunakan metode eksperimen kuantitatif tentang struktur beton pasca kebakaran dengan membuat benda uji berbentuk kubus ukuran $15 \mathrm{~cm}$ x $15 \mathrm{~cm}$ x 15 cm dengan mutu beton K-200, K-250, K300 , K-350 yang dibakar dengan durasi pembakaran selama 2 jam, 4 jam, 6 jam dan 8 jam. Beton pasca kebakaran menunjukan kuat tekan dari setiap mutu beton dan durasi pembakaran yang berbeda mengalami 
perubahan kuat tekan. Beton yang mengalami peningkatan kuat tekan pasca kebakaran adalah: Mutu beton K-200 durasi pembakaran 6 jam suhu $365{ }^{\circ} \mathrm{C}$ sebesar 29,62 MPa. Mutu beton K-300 durasi pembakaran 4 jam suhu $573{ }^{\circ} \mathrm{C}$ sebesar 21,40 MPa. Mutu Beton K-350 durasi pembakaran 4 jam suhu $493{ }^{\circ} \mathrm{C}$ sebesar $22,88 \mathrm{MPa}$. Beton yang mengalami penurunan kuat tekan pasca kebakaran adalah: Mutu beton K-200 pembakaran selama 2 jam suhu $302{ }^{\circ} \mathrm{C}, 4$ jam jam suhu $315{ }^{\circ} \mathrm{C}$ dan 8 jam suhu $396{ }^{\circ} \mathrm{C}$. Mutu beton $\mathrm{K}-250$ tidak ada yang mengalami peningkatan kuat tekan. Mutu beton K-300 pembakaran selama 2 jam suhu $332{ }^{\circ} \mathrm{C}, 6$ jam suhu $755{ }^{\circ} \mathrm{C}$ dan 8 jam $870{ }^{\circ} \mathrm{C}$. Mutu beton K-350 mengalami pembakaran selama 2 jam suhu $399{ }^{\circ} \mathrm{C}, 6$ jam dengan suhu 570 ${ }^{\circ} \mathrm{C} 8$ jam dan suhu $727^{\circ} \mathrm{C}$.

\section{Karakteristik Beton}

Beton adalah suatu material yang menyerupai batu yang diperoleh dengan membuat suatu campuran yang mempunyai proporsi tertentu dari semen, pasir dan koral atau agregat lainnya, dan air untuk membuat campuran tersebut menjadi keras dalam cetakan sesuai dengan bentuk dan dimensi struktur yang di inginkan. Beton di dapat dari pencampuran bahan-bahan agregat halus dan kasar yaitu pasir, batu, batu pecah, atau bahan semacam lainnya, dengan menambahkan secukupnya bahan perekat semen, dan air sebagai bahan pembantu guna keperluan reaksi kimia selama proses pengerasan dan perawatan beton berlangsung. Aggregat halus dan kasar, disebut sebagai bahan susun kasar campuran, merupakan komponen utama beton. Nilai kekuatan serta daya tahan (durability) beton merupakan fungsi dari banyak faktor, diantaranya ialah nilai banding campuran dan mutu bahan susun, metode pelaksanaan pengecoran dan kondisi perawatan pengerasannya [4].

\section{Beton Pasca Bakar}

Ada tiga sifat yang mempengaruhi beton bila dipanasi yaitu : koefisien muai panas, panas jenis dan daya hantar panas. Hasil penelitian juga menunjukan adanya penurunan kuat tekan beton jika terjadi kenaikan temperatur pada beton dengan agregat batu kapur dan batu silika [5].

Fenomena kebakaran pada struktur beton akan menyebabkan perubahan struktur, antara lain retak, kerusakan/keruntuhan, dan perubahan warna permukaan beton. Warna beton akan berubah sejalan dengan naiknya temperatur. Perubahan warna tesebut disebabkan karena agregat atau pasir yang mengandung beberapa senyawa besi yang juga dapat menyebabkan korosi. Perubahan warna pada beton tergantung pada tinggi tempratur yang terjadi dan lama waktu terjadinya kebakaran, semakin lama pembakaran perubahan warna beton cenderung semakin terang dan juga kerusakan pada beton semakin besar [4].

Tabel 1. Perubahan Warna dan Kondisi Beton sesuai Perubahan Suhu

\begin{tabular}{|c|c|c|}
\hline Suhu & $\begin{array}{l}\text { Warna } \\
\text { Beton } \\
\end{array}$ & Kondisi \\
\hline $0-300{ }^{\circ} \mathrm{C}$ & Normal & $\begin{array}{c}\text { Tidak Mengalami } \\
\text { Penurunan Kekuatan }\end{array}$ \\
\hline $300-600{ }^{\circ} \mathrm{C}$ & $\begin{array}{l}\text { Merah } \\
\text { jambu }\end{array}$ & $\begin{array}{c}\text { Mengalami } \\
\text { Penurunan Kekuatan }\end{array}$ \\
\hline $600-900{ }^{\circ} \mathrm{C}$ & $\begin{array}{l}\text { Putih } \\
\text { Keabu- } \\
\text { abuan }\end{array}$ & $\begin{array}{l}\text { Tidak Mempunyai } \\
\text { Kekuatan Lagi }\end{array}$ \\
\hline$>900{ }^{\circ} \mathrm{C}$ & $\begin{array}{l}\text { Kuning } \\
\text { Muda }\end{array}$ & $\begin{array}{l}\text { Tidak Mempunyai } \\
\text { Kekuatan Lagi }\end{array}$ \\
\hline
\end{tabular}

Sumber : [5]

\section{METODE PENELITIAN}

Penelitian ini dilakukan di laboratorium Fakultas Teknik Universitas Sang Bumi Ruwa Jurai dengan rincian pelaksanaan sebagai berikut :

1. Pengujian agregat halus dan kasar

2. Pembuatan benda uji

3. Pembakaran Benda uji

4. Pengujian kuat lentur dan porositas 
Adapun alat Adapun alat-alat yang digunakan dalam penelitian ini sepenuhnya alat yang ada didalam laboraorium di Laboratorium Teknik Sipil Fakultas teknik, Universitas Sang Bumi Ruwa Jurai. berikut alat-alat yang akan dipakai dalam penelitian ini, antara lain meliputi :

1. Kubus Balok Ukuran $15 \times 15 \times 15 \mathrm{~cm}$

2. Timbangan

3. Kerucut Slump

4. Mesin molen

5. Ayakan, kuas

6. Mesin furnace (oven pembakar)

7. Mesin pressing (Uji Tekan)

8. Batang perojok

9. Skrap, sekop semen

\section{Analisis Kuat Tekan beton}

Besar beban persatuan luas, yang menyebabkan benda uji hancur apabila dibebani gaya tekan yang dihasilkan dari mesin tekan. Kuat tekan merupakan sifat mutlak yang harus ada pada beton dibandingkan sifat-sifat lainnya. kekuatan sebuah beton di tentukan dari pengaturan perbandingan semen, aggregat kasar dan halus, serta air. Perbandingan air semen dapat mempengaruhi kuat tekan pada beton tersebut. Air diperlukan untuk memberikan reaksi kimia dalam pengerasan beton, kelebihan air dapat memudahkan pengerjaan tetapi akan menurunkan kekuatan beton. Berikut rumus perhitungan kuat tekan beton [6]:

Dengan :

$$
f^{\prime} c=\frac{P}{A}
$$

$f^{\prime} c=$ Kuat Tekan $\left(\mathrm{kg} / \mathrm{cm}^{2}\right)$

$A \quad=$ Luas Penampang benda uji

( Silinder) $\left(\mathrm{cm}^{2}\right)$

$P \quad=$ Beban $(\mathrm{kg})$

Nilai presentase penurunan kekuatan beton yang mengalami perubahan suhu dinyatakan dengan rumus [6]:

$$
\Delta f^{\prime} c=\frac{f^{\prime} c_{\mathrm{i}}-f^{\prime} c_{\chi}}{F^{\prime} c_{\mathrm{i}^{-}}} \times 100 \%
$$

Dimana :

$\Delta f^{\prime} c=$ Perubahan kekuatan beton (\%)

$f^{\prime} c_{i}=$ Kekuatan hancur beton pada suhu normal $/ 25^{\circ} \mathrm{C}(\mathrm{Mpa})$

$f^{\prime} c_{\chi}=$ Kekuatan hancur beton pada suhu yang ditinjau (Mpa)

Untuk tahapan penelitian dapat dilihat dalam diagram alir berikut ini :

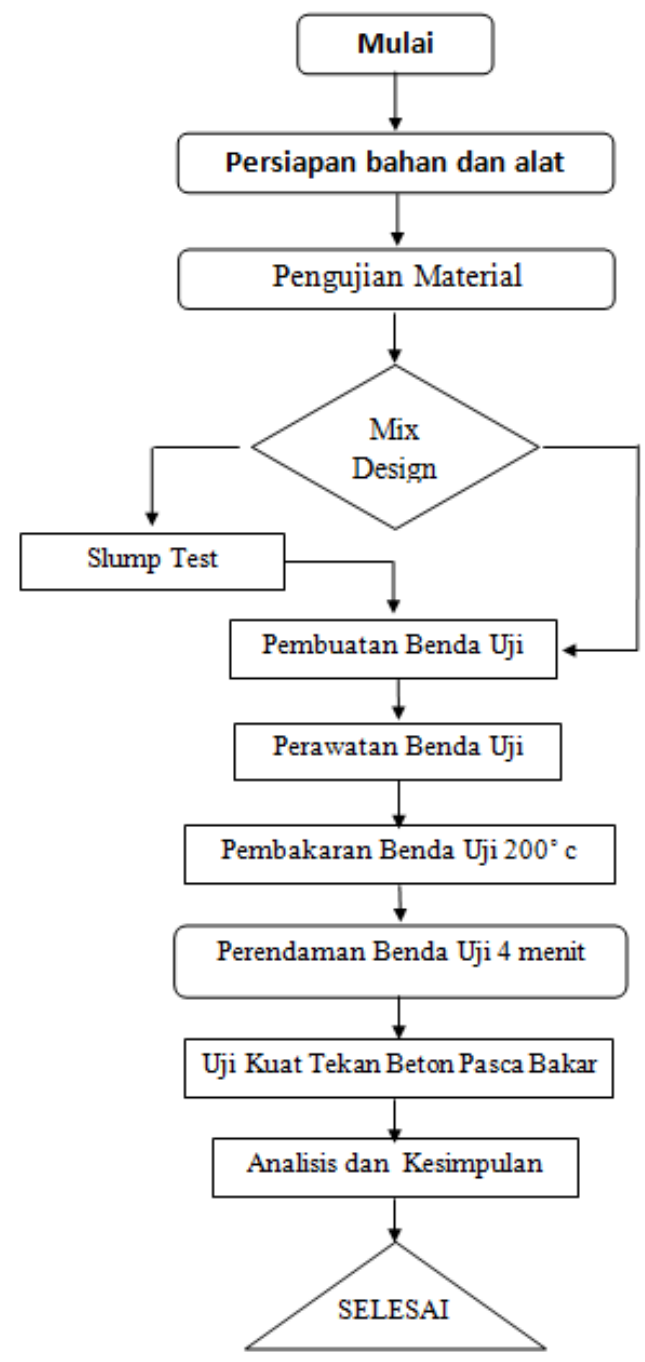

Gambar 1. Diagram Alir Penelitian

HASIL DAN PEMBAHASAN

\section{Pengujian Agregat}

Pengujian material dilakukan dengan tujuan untuk mengetahui kadar atau kandungan air yang ada di permukaan butirbutir pasir atau kerikil. Berikut merupakan hasil uji agregat halus dan agregat kasar : 
Tabel 2. Hasil Pengujian Agregat Halus

\begin{tabular}{lll}
\hline \multicolumn{1}{c}{$\begin{array}{c}\text { Jenis } \\
\text { Pengujian }\end{array}$} & \multicolumn{1}{c}{$\begin{array}{c}\text { Hasil } \\
\text { Pengujian } \\
\text { Rata-Rata }\end{array}$} & Standar Pengujian \\
\hline Kadar Air & $7,4 \%$ & AASHTO -T.112 \\
Kadar & $2,96 \%$ & AASHTO-T.112 \\
Lumpur & & SNI 03-2834-1993 \\
Serapan Air & $2,4 \%$ & SNI 03-2834-1993 \\
Berat Volume & $1,345 \%$ & SNI 03-2834-1993 \\
Modulus & $6,27 \%$ & \\
$\begin{array}{l}\text { Halus Butir } \\
\text { Gradasi }\end{array}$ & $7,17 \%$ & SNI 03-2834-1993 \\
\hline \multicolumn{2}{l}{ Sumber: Hasil Pengujian (2021) }
\end{tabular}

Tabel 3. Hasil Pengujian Agregat Kasar

\begin{tabular}{|c|c|c|}
\hline $\begin{array}{c}\text { Jenis } \\
\text { Pengujian }\end{array}$ & $\begin{array}{c}\text { Hasil } \\
\text { Pengujian } \\
\text { Rata-Rata }\end{array}$ & Standar Pengujian \\
\hline Kadar Air & $0,25 \%$ & AASHTO -T.112 \\
\hline $\begin{array}{l}\text { Kadar } \\
\text { Lumpur }\end{array}$ & $0,48 \%$ & AASHTO-T.112 \\
\hline Serapan Air & $1,57 \%$ & SNI 03-2834-1993 \\
\hline Berat Volume & $1,391 \%$ & SNI 03-2834-1993 \\
\hline $\begin{array}{l}\text { Modulus } \\
\text { Halus Butir }\end{array}$ & $7,4 \%$ & SNI 03-2834-1993 \\
\hline Gradasi & $\begin{array}{l}\text { Agregat } \\
40 \mathrm{~mm}\end{array}$ & SNI 03-2834-1993 \\
\hline
\end{tabular}

Sumber : Hasil Pengujian (2021)

\section{Perancangan Adukan beton}

Pembuatan rencana campuran beton normal menggunakan SNI 03-2834-1993 yang merupakan salah satu acuan bagi para perencana dan pelaksana dalam merencanakan proporsi campuran beton tanpa menggunakan bahan tambah untuk menghasilkan mutu beton sesuai dengan rencana [7].

Tabel 4. Agregat Campuran Beton K-250

\begin{tabular}{ccccc}
\hline Jenis & Semen & $\begin{array}{c}\text { Agregat } \\
\text { Hahan }\end{array}$ & $\begin{array}{c}\text { Agregat } \\
\text { Kasar }\end{array}$ & Air \\
\hline Berat & $405 \mathrm{Kg}$ & $815 \mathrm{Kg}$ & $1004 \mathrm{Kg}$ & 153 \\
& & & & $\mathrm{Kg}$ \\
\hline Jumlah & \multicolumn{2}{c}{$2734 \mathrm{Kg}$} & \\
\hline
\end{tabular}

\section{Uji Kuat Tekan Beton}

Benda uji dibagi dua jenis yaitu beton tanpa bakar dan beton pasca bakar. Pengujian ini untuk mengetahui berapa penurunan kekuatan yang terjadi pada beton pasca bakar.

Tabel 5. Hasil Pengujian dari beton normal

\begin{tabular}{lll}
\hline $\begin{array}{c}\text { Sampel Benda } \\
\text { Uji }\end{array}$ & $\begin{array}{c}\text { Berat Sebelum } \\
\text { dibakar }\end{array}$ & Load/kN \\
\hline Sampel 1.1 & 8310 & 556 \\
Sampel 1.2 & 8360 & 546 \\
Sampel 1.3 & 8240 & 559 \\
Sampel 1.4 & 8350 & 556 \\
Sampel 1.5 & 8370 & 572 \\
\hline Rata-Rata & 8326 & 557,8 \\
\hline \multicolumn{2}{l}{ Sumber : Hasil Pengujian, 2021 }
\end{tabular}

Berat benda uji beton tanpa bakar mendapat hasil rata-rata 8326 dan untuk kekuatan mutu beton yaitu rata-rata 557,8 $\mathrm{kN}$.

Tabel 6. Hasil Pengujian Kuat Tekan Beton Total

\begin{tabular}{lcccccc}
\hline $\begin{array}{l}\text { Durasi } \\
\text { Waktu }\end{array}$ & 1 & 2 & 3 & 4 & 5 & $\begin{array}{c}\text { Rata- } \\
\text { Rata }\end{array}$ \\
\hline $\begin{array}{l}\text { Tanpa } \\
\text { Bakar }\end{array}$ & 556 & 546 & 559 & 556 & 572 & 557,8 \\
3 Jam & 454 & 551 & 507 & 524 & 531 & 513,4 \\
$6 \mathrm{Ja}$ & 503 & 446 & 436 & 456 & 456 & 459,4 \\
9 jam & 462 & 463 & 422 & 453 & 434 & 446,8 \\
\hline \multicolumn{5}{l}{ Sumber : Hasil Pengujian (2021) }
\end{tabular}

Berikut dibawah ini tabel setelah hasil kuat tekan beton dalam KN dikonversi ke dalam $\mathrm{Kg} / \mathrm{cm}^{2}$.

Tabel 6. Hasil Pengujian Kuat Tekan Beton Total

\begin{tabular}{cccc}
\hline $\begin{array}{c}\text { Durasi } \\
\text { Waktu }\end{array}$ & $\begin{array}{c}\text { Rata- } \\
\text { Rata KN }\end{array}$ & $\mathrm{Kg} / \mathrm{cm} 2$ & Presentase \\
\hline Tanpa & 557,8 & 252,9 & Normal \\
Bakar & & & \\
3 Jam & 513,4 & 232,7 & $7,96 \%$ \\
$6 \mathrm{Ja}$ & 459,4 & 208,3 & $17,6 \%$ \\
9 jam & 446,8 & 202,5 & $19,9 \%$ \\
\hline
\end{tabular}

Sumber : Hasil Pengujian (2021)

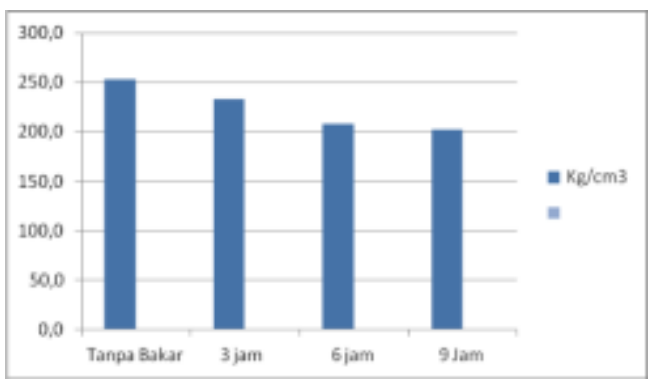

Gambar 2. Diagram Penurunan Kuat Tekan Beton 
$\left(\mathrm{Kg} / \mathrm{cm}^{2}\right)$

Dari Tabel 6 di atas dapet disimpulkan Pembakaran dengan menggunakan variasi waktu pembakaran 3 jam, 6 jam, dan 9 jam dan perendaman selama 4 menit kuat tekan beton berangsur turun, dan memiliki kuat tekan normal adalah $252 \mathrm{Kg} / \mathrm{cm}^{2}$ dan berangsur turun pembakaran 3 jam yaitu 232,7 $\mathrm{Kg} / \mathrm{cm}^{2}$, Pembakaran 6 jam mendapatkan hasil $208,3 \mathrm{Kg} / \mathrm{cm}^{2}$, dan pembakaran 9 mendapatkan hasil 202,5 $\mathrm{Kg} / \mathrm{cm}^{2}$. dari nilai diatas presentase penurunan pembakaran selama 3 jam adalah $3,85 \%$, Pembakaran 6 jam adalah $8,4 \%$, dan $9 \mathrm{Jam}$ adalah $9,6 \%$. Adapun hasil pengujian kuat tekan beton pasca bakar, disini bisa ditarik kesimpulan durasi waktu pembakaran, sangat mempengaruhi penurunan kuat tekan beton itu sendiri. pembakaran memberikan perbedaan pengaruh yang signifikan terhadap penurunan kuat tekan beton.

\section{KESIMPULAN}

Setelah melakukan penelitian dan analisa pada hasil pengujian, dapat disimpulkan beberapa hal sebagai berikut :

1. Besarnya pengaruh dari perubahan tempratur tinggi relatif sesuai dan nilai kuat tekan beton rata-rata yang

\section{DAFTAR PUSTAKA}

[1] S. U. Dewi, F. H. Jaya, M. A. Khairil, and K. Tekan, "PASCA BAKAR," vol. 11, no. 1, 2021.

[2] U. Ukiman, S. Utomo, I. Nurhadi, and ..., "Karateristik Baja Tulangan Polos Pada Mutu Beton K 175 Tebal Selimut $3 \mathrm{Cm}$ Terbakar Dengan Durasi Yang Berbeda," Wahana Tek. Sipil ..., vol. 13, no. 2, pp. 137-143, 2016.

[3] R. Cornelis, E. Hunggurami, and N. dihasilkan pasca bakar selalu mengalami penurunan.

2. Nilai kuat tekan rata-rata pada beton pasca bakar dan perendaman selama 4 menit ialah pembakaran 3 jam Mengalami penuruanan sebesar $8 \%$, pembakaran 6 jam Mengalami penuruanan sebesar 17,5\%, pembakaran 3 jam Mengalami penuruanan sebesar $19.9 \%$.

3. Karakteristik dan sifat fisik beton setelah menerima temperatur tinggi beton belum mengalami kerusakan bentuk fisik dikarenakan temperatur terlampau kecil hanya mengurangi kekuatan dari beton tersebut, dikarnakan masih memakai suhu rendah yaitu $200{ }^{\circ} \mathrm{C}$.

4. Pada tiap durasi pembakaran beton selalu mengalami penyusutan berat, diketahui pembakaran 3 jam mengalami penyusutan $0,67 \%$, dan 6 jam mengalami penyusutan sekitar 2,49\%, sedangkan durasi pembakaran 9 jam mengalami penyusutan sekitar $3,1 \%$ dari berat rata-rata beton tanpa bakar.

5. Suhu yang digunakan untuk pembakaran pada penelitian ini yaitu $200^{\circ} \mathrm{C}$ masih dapat ditoleransi. penurunan kekuatan benda uji tidak menurun terlalu signifikan dan beton mash bisa digunakan kembali setalah masa perawatan kembali.

Y. Tokang, "Kajian Kuat Tekan Beton Pasca Bakar Dengan Dan Tanpa," vol. III, no. 2, pp. 161-172, 2014.

[4] J. Juhariadi, A. Novan, and A. Kurniawandy, "Pengaruh Variasi Suhu dan Durasi Pembakaran terhadap Kuat Tekan Beton Pasca Bakar," Neliti.Com, vol. 2, no. 1, pp. 1-11, 2015.

[5] F. R. Atmaja, D. Triana, and R. Ujianto, "Struktur Beton Pasca Kebakaran Terhadap Kuat Tekan 
Dan Karakteristik Beton," $J$. CIVTECH Tek. Sipil Univ. Serang Raya, vol. 1, no. 1, pp. 1-13, 2017.

[6] Y. Afrizal et al., "ANALISIS KEKUATAN BETON PASCABAKAR DENGANMETODE NUMERIK," Teknosia, vol. 1, no. 13, pp. 21-28.

[7] SK SNI 15-1991-03, "Tata Cara Perhitungai Struktur Beton Untuk Bangunan Gedung," Sk Sni T151991-03, p. 520, 1991. 